Int. J. Electrochem. Sci., 13 (2018) $2310-2328$

\title{
Investigation of Carbon Allotropes for Simultaneous Determination of Ascorbic Acid, Epinephrine, Uric Acid, Nitrite and Xanthine
}

\author{
Masoumeh Tohidinia, Meissam Noroozifar ${ }^{*}$ \\ Department of Chemistry, University of Sistan and Baluchestan, Zahedan, P.O. Box 98135-674, Iran \\ *E-mail: $\underline{\text { mnoroozifar@chem.usb.ac.ir }}$
}

doi: $10.20964 / 2018.03 .122$

Received: 2 October 2017 / Accepted: 23 December 2017 / Published: 5 February 2018

\begin{abstract}
In this study, modified glassy carbon electrode (GCE) with different carbon allotropes such as multiwall carbon nanotubes (MWCNTs), graphene, bucky ball and graphite have been used for the simultaneous determination of ascorbic acid (AA), epinephrine (EP), uric acid (UA), Nitrite $\left(\mathrm{NO}_{2}{ }^{-}\right)$, and xanthine $(\mathrm{XN})$. Different electrochemical methods such as cyclic voltammetry, differential pulse voltammetry and chronoamperometry methods were employed to study the behavior of AA, EP, UA, $\mathrm{NO}_{2}^{-}$and $\mathrm{XN}$ on these proposed modified electrodes. The modified GCE with MWCNTs was successfully used for simultaneous determination of $\mathrm{AA}, \mathrm{EP}, \mathrm{UA}, \mathrm{NO}_{2}{ }^{-}$and $\mathrm{XN}$. The electron transfer coefficients, diffusion coefficients and standard heterogeneous rate constant were determined for the electrochemical oxidation of AA, EP, UA, $\mathrm{NO}_{2}{ }^{-}$and $\mathrm{XN}$. Under the optimum conditions, detection limits of 16.3, 3.92, 0.37, 29.9 and $0.13 \mu \mathrm{M}$ were obtained for AA, EP, UA, $\mathrm{NO}_{2}{ }^{-}$, and $\mathrm{XN}$, respectively. Moreover, the best modified GCE was applied for simultaneous determination of AA, $\mathrm{EP}, \mathrm{UA}, \mathrm{NO}_{2}{ }^{-}$, and $\mathrm{XN}$ in Human urine, serum and $\mathrm{AA}$ Tables samples.
\end{abstract}

Keywords: Carbon allotropes, Simultaneous determination, Bio-compounds, Nitrite.

\section{$\underline{\text { FULL TEXT }}$}

(C) 2018 The Authors. Published by ESG (www.electrochemsci.org). This article is an open access article distributed under the terms and conditions of the Creative Commons Attribution license (http://creativecommons.org/licenses/by/4.0/). 